\title{
PROBLEMATIKA PEMBELAJARAN ANAK USIA DINI DI MASA COVID-19
}

\author{
Gusnarib Wahab \\ gusnarib@iainpalu.ac.id \\ Fakultas Tarbiyah dan Ilmu Keguruan IAIN Palu \\ M. Iksan Kahar \\ m_iksankahar@iainpalu.ac.id \\ Fakultas Tarbiyah dan Ilmu Keguruan IAIN Palu
}

\begin{abstract}
Education, which was originally using a direct method in educational institutions, is now transformed into online learning and carried out from each home to prevent the spread of the COVID-19 virus. This policy applies to all levels of education, from early childhood or kindergartens to tertiary levels. This raises many problems, especially the implementation of learning for early kindergartens level. Learning using an online system still experiences many problems in its application, because children cannot learn on their own without assistance from their parents. In encouraging the quality of learning in early childhood, cooperation and support from parents is needed. Parents are responsible for the sustainability of early childhood education during the Covid-19 period. Positive parenting, the provision of an adequate learning environment, and relevant learning resources will greatly assist early childhood in undergoing the transition period to the new normal era. Therefore, communication between teachers and parents must go well. The government's policy on learning from home does not necessarily make teachers give up their duties in providing education to early childhood. In fact, this requires teachers to improve their competence in conducting distance learning and continue to assess children's development based on activity reports from parents.
\end{abstract}

Keywords: Learning Problems, Early Childhood, kindergarten schools, Covid-19. 
Abstrak

Pendidikan yang semula dengan metode tatap muka di lembaga pendidikan, kini diubah menjadi pembelajaran daring/online dan diaksanakan dari rumah masing-masing untuk mencegah dan menanggulangi penyebaran virus COVID-19 ini. Kebijakan tersebut berlaku bagi semua jenjang pendidikan baik dari tingkat PAUD hingga tingkat perguruan tinggi. Hal tersebut menimbulkan banyak problematika khususnya pelaksanaan pembelajaran bagi anak usia dini. Pembelajaran dengan menggunakan sistem daring ataupun sistem online ini masih mengalami banyak problematika dalam penerapannya, karena anak tidak dapat belajar sendiri tanpa pendampingan dari orang tua. Dalam mendorong kualitas pembelajaran pada Anak Usia Dini perlu kerjasama dan dukungan orang tua. Orang tua menjadi salah satu pihak yang bertanggung jawab dalam keberlangsungan pendidikan anak usia dini di masa covid19. Pengasuhan positif, penyediaan lingkungan belajar yang memadai, dan sumber belajar yang relevan akan sangat membantu anak usia dini dalam menjalani masa transisi menuju era new normal. Oleh karena itu, komunikasi antara guru dan orang tua harus berjalan dengan baik. Kebijakan pemerintah tentang belajar dari rumah tidak serta merta membuat guru melepaskan tugasnya dalam memberikan pendidikan kepada anak usia dini. Justru hal tersebut menuntut guru untuk meningkatkan kompetensinya dalam melakukan pembelajaran jarak jauh dan tetap menilai perkembangan anak berdasarkan laporan kegiatan dari para orang tua.

Kata Kunci: Problematika Pembelajaran, Anak Usia Dini, PAUD, Covid-19.

\section{PENDAHULUAN}

Pandemi covid-19 mempengaruhi semua aktivitas kehidupan manusia mulai aktivitas olahraga, perkantoran, bahkan sampai pada hubungan transedental bagi seluruh pemeluk agama di dunia tidak terkecuali dengan bidang pendidikan. Aktivitas pendidikan yang sangat lekat dengan interaksi yang melibatkan 
banyak orang; pendidik dengan para peserta didik dalam satu lingkungan belajar secara langsung bertatap muka. Karena pandemi covid-19 interaksi secara langsung dihentikan (social distancing) dan diganti dengan aktivitas pembelajaran jarak jauh (daring) dengan memanfaatkan media internet. Hal ini berlaku untuk seluruh jenjang pendidikan mulai dari pendidikan tinggi, pendidikan menengah, sekolah dasar maupun untuk pendidikan anak usia dini. Lembaga-lembaga PAUD yang sangat intens dalam melakukan stimulasi perkembangan anak usia dini melalui kegiatan bermain sambil belajar di ruang-ruang kelas, karena adanya covid-19 diganti dengan pembelajaran di rumah masingmasing.

Pandemi COVID-19 menimbulkan dampak yang signifikan terhadap pola pendidikan khususnya di negara Indonesia. Indonesia adalah salah satu negara yang terdampak COVID-19 dan hingga saat ini, Indonesia masih catatkan angka kematian tertinggi di Asia Tenggara. Guru mengantisipasi jumlah penularan yang kian hari semakin naik, pemerintah mengeluarkan kebijakan seperti isolasi mandiri, social and physical distancing hingga pembatasan sosial berskala besar di berbagai kota. Kondisi tersebut mewajibkan setiap warga untuk tetap tinggal di rumah, bekerja dan belajar di rumah. ${ }^{1}$

Dunia pendidikan harus senantiasa menyesuaikan perkembangan teknologi terhadap usaha dalam meningkatkan mutu pendidikan, terutama penyesuaian penggunaan teknologi informasi dan komunikasi bagi dunia pendidikan khususnya dalam proses pembelajaran. Implementasi pemanfaatan teknologi informasi dan komunikasi dalam dunia pendidikan salah satunya dapat diwujudkan melalui pembelajaran dalam jaringan (daring). Melaui pembelajaran daring tidak mengharuskan guru dan peserta didik saling bertatap muka.

Wabah pandemi Covid-19 yang melanda ke seluruh dunia, telah merubah tatanan kehidupan di segala bidang dengan adanya kebijakan menjaga jarak fisisk (physical distancing) dan jaga jarak sosial (social distancing). Dunia pendidikan dari semua jenjang

${ }^{1}$ Jamaluddin, dkk., Pembelajaran Daring Masa Pandemi Covid-19 pada Calon Guru: Hambatan, Solusi dan Proyeksi (Bandung: UIN Sunan Gunung Djati Bandung, 2020), h. 2. 
pendidikan termasuk pendidikan anak usia dini (PAUD) juga merasakan dampaknya. Pembelajaran di rumah dengan sistem daring merupakan pilihan yang tidak bisa dihindari, sehingga menimbulkan masalah baru dalam bidang pendidikan. Banyak tantangan dan hambatan dalam pelaksanaan pembelajaran di rumah, baik oleh institusi pendidikan, guru, peserta didik dan orang tua. Dengan belajar jarak jauh tentu dirasakan sangat berbeda jika dibandingkan dengan belajar di sekolah, baik dari segi proses pembelajaran, metode belajar, respon peserta didik terhadap materi pelajaran, dan kesehatan mental-sosial. ${ }^{2}$

Wabah Covid 19 telah menyebar di Indonesia yang awalnya berasal dari kota Wuhan Cina sejak desember 2019. WHO menyatakan ini sebagai pandemi global karena penularan virus ini sangatlah cepat. Oleh karena itu, setiap negera wajib menerapkan upaya untuk pencegahan penyebaran covid-19 dengan cara social distanching (pembatasan jarak sosial) untuk mengurangi interaksi antar individu dalam komunitas yang lebih luas. ${ }^{3}$ Kondisi tersebut memaksa terjadinya perubahan termasuk dalam dunia Pendidikan mulai dari Taman Kanak-Kanak (TK) hingga perguruan tinggi yang awalnya menggunakan metode tatap muka atau face to face saat pembelajaran kini perlu mengubahnya menjadi pembelajaran dalam jaringan (daring) dan luar jaringan (luring). ${ }^{4}$ Hal ini sesuai dengan anjuran Pemerintah yang diberitahukan melalui (Surat Edaran Tentang Pedoman Penyelenggaraan Belajar Dari Rumah Malam Masa Darurat Penyebaran Corono Virus Disease (COVID19) Nomor 15 Tahun 2020 yang menyatakan bahwa pembelajaran dilaksanakan dari rumah menggunakan pembelajaran jarak jauh (daring/e-learning) serta dalam jaringan (daring/offline)

${ }^{2}$ Cipta Pramana, Pembelajaran Pendidikan Anak Usia Dini (PAUD) Dimasa Pandemi Covid-19, Indonesian Journal of Early Childhood: Jurnal Dunia Anak Usia Dini, Volume 2 Nomor 2Juli 2020, 123.

${ }^{3}$ Wilder-Smith, A., \& Freedman, D. O. Isolation, quarantine, social distancing and community containment: Pivotal role for old-style public health measures in thenovel coronavirus $(2019-\mathrm{nCoV})$ outbreak. Journal of Travel Medicine, 27(2) 2020, 1-4.https://doi.org/10.1093/jtm/taaa020

${ }^{4}$ Napitupulu, Dampak pandemi Covid-19 terhadap kepuasan pembelajaran jarak jauh. Jurnal Inovasi Teknologi Pendidikan, 7(1) 2020, 23-33. https://doi.org/10.21831/jitp.v7i1.32771 
dan hanya boleh dilaksanakan daerah zona hijau yang mematuhi protokol kesehatan.

Himbauan dari Pemerintah sesuai dengan protokol kesehatan tentang prosedur pencegahan penyebaran virus Covid-19 semua kegiatan sekolah harus ditiadakan dan anak-anak belajar dari rumah dan semua guru harus bekerja dari rumah. Dengan penerapan Work From Home (WFH) maka semua pihak harus mematuhi aturan yang diberikan. Dengan adanya himbauan ini , guru agar tetap memantau dan memberikan kegiatan kepada murid melalui pembelajaran dalam jaringan (daring). Sebuah tantangan baru bagi guru Pendidikan Anak Usia dini, yang selama ini belum pernah menggunakan penerapan pembelajaran dalan jaringan untuk kegiatan belajar mengajar. Dengan adanya WFH pada jenjang Pendidikan Anak Usia Dini diharapkan guru tetap bisa memantau perkembangan dan kegiatan anak di rumah, dan terus berinteraksi dengan anak dan orang tua.

Pendidikan yang semula dengan metode tatap muka di lembaga pendidikan, kini diubah menjadi pembelajaran daring/online dan dilaksanakan dari rumah masing-masing untuk mencegah dan menanggulangi penyebaran virus COVID-19 ini. Kebijakan tersebut berlaku bagi semua jenjang pendidikan baik dari tingkat PAUD hingga tingkat perguruan tinggi. Hal ini merupakan langkah inisiatif dari pemerintah karena pembelajaran tidak harus bertemu langsung, tidak harus bertatap muka langsung, namun dilaksanakan melalui sosial media, dan berbagai aplikasi lainnya yang menunjang pembelajaran daring.

Pembelajaran dalam jaringan (daring/e-learning) adalah suatu sistem rancangan pembelajaran dimana penerapannya menggunakan jaringan internet dan dilakukan secaratidak langsung antara guru maupun peserta didik, dengan waktu pembelajaran materi pembelajaran yang sama dengan mengirimkan teks, audio, gambar, animasi dan video streaming serta aplikasi yang berbasis website belajar yang digunakan melalui jaringan internet. ${ }^{5}$ Pemerintah juga menyiapkan beberapa fasilitas untuk menunjang pembelajaran jarak jauh seperti: siaran pembelajaran melalui TV

${ }^{5}$ Sri, E-Learning: Technological Development in Teaching for school kids. International Journal of Computer Science and Information Technologies, 5(5) 2014, 6124-6126. 
dan radio serta penyediaan kuota gratis/murah. ${ }^{6}$ Sedangkan pembelajaran luar jaringan (luring) adalah suatu sistem pembelajaran yang didalamnya ada beberapa metode seperti kunjungan rumah (home visit) dan shift (bergantian) dengan menggunakan media, materi, lembar kerja anak (LKS), alat peraga, media, modul belajar mandiri, dan bahan ajar cetak yang berada disekitar lokasi lingkungan rumah yang telah dipersiapkan oleh pendidik. $^{7}$

Pembelajaran daring menuntut semua pihak mulai dari guru, orang tua serta murid saling bekerja sama. ${ }^{8}$ Kerja sama yang dilakukan seperti guru sebagai perencana kegiatan dan penilai hasil pembelajaran sedangkan orang tua sebagai pembimbing anak saat di rumah dalam memantau proses pembelajaran. ${ }^{9}$ Guru juga harus bekerja lebih kreatif dan ekstra dalam mempersiapkan perencanaan pembelajaran (bahan, materi, metode serta RPPH) pelaksanaan, serta evaluasi yang digunakan saat proses pembelajaran daring yang berbeda dari sebelum terdampak covid 19, sehingga dapat menarik minat maupun semangat belajar peserta didik. ${ }^{10}$

Selain itu orang tua juga memilki peran yang sangat penting dalam membantu anaknya dalam proses pembelajaran saat di rumah seperti membimbing dalam menggunakan teknologi yang dipakai saat belajar serta memberikan semangat, motivasi, dan dukungan dalam melaksanakan pembelajaran sehingga memperoleh prestasi yang baik. Namun dibalik peran orang tua yang sangat penting, terdapat tantangan bagi orang tua yang tentunya sangat mempengaruhi bagi anak saat proses pembelajaran

${ }^{6}$ Hamid, Menyiapkan Pembelajaran Di Masa Pandemic: Tantangan Dan Peluang. Kementerian Pendidikan dan Kebudayaan, 2020.

${ }^{7}$ Suhendro, Strategi Pembelajaran Pendidikan Anak Usia Dini di Masa Pandemi Covid-19. Jurnal Golden Age, 5(3) 2020, 133-140.

${ }^{8}$ Khadijah, \& Gusman, M. Pola kerja sama guru dan orangtua mengelola bermain AUD selama masa pandemi covid-19. Jurnal Kumara Cendekia, 8(2) 2020, 154-171.

${ }^{9}$ Hewi, L., \& Asnawati, L. Strategi Pendidik Anak Usia Dini Era Covid19 dalamMenumbuhkan Kemampuan Berfikir Logis. Jurnal Obsesi: Jurnal Pendidikan Anak Usia Dini, 5(1) 2020, 158. https://doi.org/10.31004/obsesi.v5i1.530

${ }^{10}$ Fahrina, et.al. Minda Guru Indonesia: Peran Guru Dan Keberlangsungan Pembelajaran di Masa Pandemi Covid-19. Syiah Kuala University Press, 2020. 
yaitu penurunan kemampuan ekonomi orang tua sehingga berdampak pada ketindaknyamanan anak saat berada di rumah.

Hal di atas tentu menimbulkan banyak problematika khususnya pelaksanaan pembelajaran bagi anak usia dini. Anak usia dini adalah tahapan dalam masa emas yang memerlukan pelayanan lebih, secara khusus dan langsung bila dibandingkan jenjang pendidikan lain. Anak usia dini merupakan masa emas (golden age) yang hanya ada sekali periode dalam kehidupannya dan tidak dapat diulang kembali. ${ }^{11}$ Adanya wabah COVID ini menimbulkan dampak bagi para pendidik. Para pendidik merasa kesulitan dalam mengembangkan pembelajarannya. Proses pembelajaran yang sebelumnya dilakukan secara langsung dengan mencapai seluruh aspek baik kognitif, afektif, maupun psikomotorik kini berubah menjadi pembelajaran daring atau pembelajaran jarak jauh. Hal ini sangat berpengaruh kepada tumbuh kembang anak usia dini. Dunia anak merupakan dunia bermain yang cenderung melibatkan anak berinteraksi langsung, bertatap muka langsung, dan terlibat dalam beberapa kegiatan. Tatap muka langsung ini akan memberikan motivasi-motivasi bagi anak. Pendidikan Anak Usia Dini adalah pendidikan yang memiliki peranan strategis untuk mengembangkan potensi awal bagi anak, untuk memenuhi tumbuh kembang anak agar anak memiliki pondasi dan kesiapan dalam mengikuti pendidikan dalam jenjang selanjutnya. ${ }^{12}$

Pendidikan Anak Usia Dini merupakan jenjang pendidikan yang harus menjadi perhatian serius bagi seluruh pihak, jangan sampai dengan pembelajaran daring maka aspek tujuan dari pembelajaran anak usia dini akan terabaikan. Hal ini akan sangat berdampak terhadap potensi awal dan tumbuh kembang anak. Bila ini dibiarkan maka anak akan kehilangan pondasi awal dan kesiapan dalam mengikuti pendidikan kedepan. Proses pendidikan daring ini adalah transformasi pendidikan tatap muka ke dalam

${ }^{11}$ Eko Suhendro \& Syaefudin, Nilai-Nilai Kemanusian dalam Pendidikan Anak Usia Dini Inklusi. JEA (Jurnal Edukasi AUD), 6(1) 2020, h. 112. https://doi.org/10.18592/jea.v6i1.3430

${ }^{12}$ Sudrajat, dkk. Strategi Kepala TK dalam Meningkatkan Mutu Pendidikan pada Masa Pandemi Covid 19 Jurnal Obsesi: Jurnal Pendidikan Anak Usia Dini, 5(1) 2020, 508-520 https://doi.org/10.31004/obsesi.v5i1.582 
bentuk digital yang tentunya memiliki peluang dan tantangan yang sangat berat. Oleh karena itu, adanya problematika yang terdapat dalam proses pembelajaran pada Anak Usia Dini harus dapat ditemukan solusi pemecahannya.

\section{PEMBAHASAN}

\section{Problematika Pembelajaran Anak Usia Dini di Masa Covid-19}

Problematika berasal dari bahasa Inggris "problematic" yang berarti masalah atau persoalan. ${ }^{13}$ Problematika berasal dari kata problem yang dapat diartikan permasalahan atau masalah. Adapun masalah itu sendiri adalah suatu kendala atau persoalan yang harus dipecahkan dengan kata lain masalah merupakan kesenjangan antara kenyataan dengan suatu yang diharapkan dengan baik, agar tercapai hasil yang maksimal. Problematika juga berarti masih menimbulkan masalah; hal-hal yang masih menimbulkan suatu masalah yang masih belum dapat dipecahkan. ${ }^{14}$ Dengan demikian, keberhasilan pembelajaran sangat ditentukan seberapa jauh guru mampu meminimalisir atau menyelesaikan problem pembelajaran.

Pendidikan Anak Usia Dini adalah suatu proses pembinaan tumbuh kembang anak usia lahir hingga enam tahun secara menyeluruh, yang mencakup aspek fisik maupun non fisik dengan memberikan rangsangan bagi perkembangan jasmani, rohani (moral dan spiritual), motorik, akal pikir, emosional dan sosial yang tepat agar anak dapat tumbuh dan berkembang secara optimal. $^{15}$

Pandemi COVID-19 menyebabkan perubahan tatanan kehidupan dunia khususnya tatanan masyarakat di negara Indonesia. Salah satu perubahan yang sangat nyata adalah pelaksanaan pendidikan menjadi "Belajar dari Rumah". Rumah umumnya dipandang sebagai tempat belajar informal. Pembelajaran informal tidak terstruktur dan peserta didik

${ }^{13}$ John M. Echols dan Hasan Shadily, Kamus Inggris-Indonesia (Jakarta: Gramedia, 2000), h. 440.

${ }^{14}$ Pusat Bahasa Depdiknas, Kamus Besar Bahasa Indonesia (Jakarta: Balai Pustaka, 2005), h. 896.

${ }^{15}$ M. Iksan Kahar, Pendidikan Karakter pada Anak Usia Dini dalam Perspektif Islam, Musawa: Journal For Gender Studies, Vol 11(01) 2019, 131. 
bertanggung jawab atas pembelajaran mereka."Belajar dari Rumah" dimana anak berada di rumah mengikuti pembelajaran dengan guru dari tempat berbeda, dikenal sebagai pembelajaran jarak jauh. ${ }^{16}$

Menjalani kegiatan di rumah, isolasi, atau karantina mandiri selama masa pandemi virus corona mungkin terasa sangat menjemukan bagi setiap orang tetapi akan lebih menjenuhkan yang di alami oleh anak-anak dimana anak-anak pada usia 4-5 tahun adalah usia penjelajah dan eksploratif dimana anak tidak bisa untuk berdiam diri. Stay at home bagi orang tua yang menjenuhkan masih bisa di atasi oleh beberapa aktivitas, lain halnya dengan anak-anak, aktivitas yang dilakukan oleh anak-anak memerlukan teman untuk bermain dan bereksplorasi. Bagi anak-anak bermain dengan teman dapat mengusir kejenuhan dan pembelajaran, hal itu tentunya perlu di dapat di luar rumah. Perasaan terkurung dan pertanyaan kapan semua ini akan bisa menjadi pemicu stress saat pandemi virus corona seperti saat ini. ${ }^{17}$

Pembelajaran dengan menggunakan sistem daring ataupun sistem online ini masih mengalami banyak problematika dalam penerapannya, karena anak tidak dapat belajar sendiri tanpa pendampingan dari orang dewasa yang paham cara mengoperasionalkan HP berbasis android. Ketersedian paket data juga menjadi hal yang perlu diperhitungkan dalam menerapkan pembelajaran dengan menggunakan aplikasi WA karena tanpa paket data maka pembelajaran yang menggunakan aplikasi WA ini tidak akan terlaksana. Letak geografis suatu daerah juga mempengaruhi kelancaran dari pembelajaran dengan menggunakan aplikasi WA karena apabila daerah peserta didik berada di daerah yang tidak terjangkau sinyal maka akan membuat komunikasi pembelajaran menjadi terputus-putus. Keberadaan sarana sangat penting untuk dimiliki dalam rangka melaksanakan pembelajaran dengan menggunakan aplikasi WhatsApp yang

16 Elviawaty Muisa Zamzami, Aplikasi Edutainment Pendukung Pembelajaran Jarak Jauh TK Merujuk Standar Nasional PAUD. Jurnal Obsesi : Jurnal Pendidikan Anak Usia Dini, 5(2) 2020, h. 985-995. https://doi.org/10.31004/obsesi.v5i2.750

${ }^{17}$ A. Tabi' in, Problematika Stay At Home Pada Anak Usia Dini Di Tengah Pandemi Covid 19, Jurnal Golden Age, Universitas Hamzanwadi Vol. 04 No. 1, Juni 2020, 194. 
terdapat dalam HP android. Hal ini dikarenakan banyak masyarakat yang belum mengenal dan memahami HP berbasis android.

Kendala yang dihadapi para orang tua adalah adanya penambahan biaya pembelian kuota internet bertambah, teknologi online memerlukan koneksi jaringan internet dan kuota oleh karena itu tingkat penggunaaan kuota internet akan bertambah dan akan menambah beban pengeluaran orang tua untuk melakukan permbelajaran online selama beberapa bulan tentunya akan diperlukan kuota yang lebih banyak lagi dan secara otomatis akan meningkatkan biaya pembelian kuota internet. Kendala selanjutnya yang dirasakan orang tua yaitu mereka harus meluangkan lebih ekstra waktu kepada anak anak mendampingi belajar online, tentunya akan berpengaruh pada aktivitas pekerjaan rutin seharihari yang akan menjadi berkurang, terkadang para orang tua juga ikut belajar bersama anak-anaknya dan ikut membantu mengerjakan tugas bersama-anak anaknya. ${ }^{18}$

Anak usia dini merupakan anak yang sedang berkembang segala aspek perkembangan dan pertumbuhan pada dirinya dengan pesat. Orang tua diharapkan mempunyai pengetahuan dan kesadaran untuk menstimulasi dengan baik segala aspek pertumbuhan dan perkembangan anak. Akan tetapi, saat ini banyak orang tua yang kurang memahami akan hal ini. Bahkan ketika anak merasa bosan, orang tua mencari cara aman dan mudah untuk mengatasi hal tersebut, misalnya memberikan gadget pada anak. Hal ini sebaliknya akan memberikan efek kecanduan dan beberapa faktor kurang baik yang akan mempengaruhi perkembangan dan pertumbuhan anak. Apalagi selama pandemi covid-19 saat ini. Anak hanya berada di dalam rumah bersama orang tua, mengikuti pembelajaran daring dan melakukan semua kegiatan di dalam rumah, sehingga gadget menjadi sahabat anak dan sahabat orang tua selama belajar di rumah.

Ketertarikan anak terhadap gadget dikarenakan banyak hal yang memang menarik darinya. Baik berupa game dan juga fitur-

${ }^{18}$ M. Iksan Kahar, Pendidikan Anak Usia Dini di Masa Covid-19, Ana'Bulava: Jurnal Pendidikan Anak 1, No. 2 (2020), 25. 
fitur menarik lainnya. Hal ini yang tidak akan ditemukan anak pada media lainnya, seperti buku, majalah, komik dan lain sebagainya. Anak bisa mengakses segala hal yang diinginkannya secara tak terbatas. Inilah yang menyebabkan anak betah berlamalama dengan gadget sehingga tidak memperdulikan kesehatan dan lingkungan sekitarnya. ${ }^{19}$

Selain kecanduan gadget dan barang elektronik lainnya, sudah pasti banyak kendala-kendala yang terjadi di rumah dan banyak keluhan dari anak-anak tentang kapan pandemi ini akan berakhir, kapan mereka akan masuk sekolah dan kapan bisa bermain di luar rumah bersama teman-teman lagi. Saat orang tua mengalami kecemasan berlebihan, stress terkait pekerjaan, tak jarang hal ini akan melimpahkannya pada anak. Anak akan menangkap sinyal-sinyal emosi negatif dari perlakuan orang tua, misalnya anak jadi ikut cemas, rewel, tantrum bahkan sering mencari perhatian. Hal ini akan menjadi beban bagi orang tua bila tidak paham apa yang harus mereka lakukan. ${ }^{20}$

Peran orang tua akan sangat berpengaruh dalam membentuk karakter anak. Orang tua merupakan teladan bagi anak untuk berperilaku, berbicara serta bersosialisasi dengan dunia luar. Peran orang tua sangat diharapkan dalam proses belajar di rumah. Diharapkan orang tua bisa mendampingi ketika anak belajar atau turut belajar bersama anak. Bisa membimbing, mengarahkan bahkan harus bisa mendidik bagi anaknya menggantikan peran guru yang biasanya mengajar di sekolah. Sejalan dengan perkembangan tekonologi saat ini, banyak orang tua yang merasa terbantu dalam mengasuh dan mendidik anakanaknya. Hal ini dibuktikan dengan adanya varian gadget yang meliputi smartphone, laptop, kamera, tablet dan sebagainya. Tetapi dewasa ini, realitanya kebanyakan orang tua masih keliru menggunakan gadget yang seharusnya dapat mengedukasi anakanak mereka. Sebaliknya, orang tua memberikan penguasaan penuh terhadap gadget untuk anak tanpa disandingkan dengan

${ }^{19}$ Jordan Efraim Palar, Franly Oniba dan Wenda Oroh, "Hubungan Peran Keluarga dalam Menghindari Dampak Negatif Penggunaan Gadget pada Anak dengan Perilaku Anak dalam Penggunaan Gadget di Desa Kiawa 2 Barat Kecamatan Kawangkoan Utara”, Volume 6 Nomor 2, 2008, h. 2-5

${ }^{20}$ Republika, "Hubungan Ibu-Anak Hadapi Stres Social Distancing Covid-19”, Minggu, 22 November 2020. 
batasan dan pengawasan. Hal ini akan berdampak, secara langsung maupun tidak langsung menjadi boomerang bagi orang tua ketika anak mereka lebih banyak menghabiskan waktu dengan gadget dibandingkan bersosialisasi dengan keluarga maupun orang lain.

\section{Solusi Alternatif Pembelajaran Anak Usia Dini di Masa Covid- 19}

Kebijakan belajar di rumah, membuat para guru, termasuk di jenjang PAUD, diharapkan segera beradaptasi. Pembelajaran yang biasanya dilakukan tatap muka disekolah, kini harus dilakukan belajar secara jarak jauh dengan mempergunakan teknologi komunikasi. Dengan platform pembelajaran yang baru sehingga guru PAUD harus memiliki kemampuan dan keterampilan mengoperasikan teknologi tersebut, merencankan pembelajaran jarak jauh yang menyenangkan yang masih sesuai dengan kurikulum pendidikan.

Beberapa keterampilan yang harus dimiliki oleh duru PAUD dalam era digital adalah:

a. Guru harus mampu dan cepat beradaptasi denga teknologi informasi, karena belajar dari rumah harus menggunakan perangkat teknologi tersebut. Selain aplikasi daring menggunakan WhatssAp juga bisa menggunakan Zoom atau Google meeting. Pembelajaran daring untuk anak usia 5-6 tahun bisa untuk topik pembelajaran misalnya bercerita, bernyanyi dan lain-lain. Dengan durasi yang tidak terlalu lama mungkin maksimal 20 menit saja.

b. Guru PAUD dituntut kreatif dan inovatif. Misalnya mengajak untuk membuat karya di rumah misalnya membuat pot dari botol plastik, menanam tanaman bunga atau sayuran di dalam pot, membuat boneka tangan menggunakan kaos kaki bekas bersama orang tua, dan lain-lain.

c. Guru PAUD harus memiliki kemampuan berkomunikasi yang baik dengan orang tua murid, hal ini sangat penting dalam membantu kelancaran proses belajar di rumah. Komunikasi dilakukan bukan hanya saat berlangsungnya proses belajar-mengajar, tetapi bisa dilakukan kapan saja sesuai kebutuhan dalam rangka penilaian dan evaluasi pembelajaran. Komunikasi yang rutin juga dibutuhkan dalam upaya terlaksananya tumbuh kembang anak secara maksimal serta menjaga agar anak tetap sehat di tengah pandemi Covid- 
19 dengan selalu mengingatkan kepada orang tua tentang protokol kesehatan. ${ }^{21}$

Tanggung jawab terbesar yang harus dilakukan orang tua yakni memastikan anak-anak dapat tumbuh dan berkembang dengan baik sesuai dengan tahap-tahap perkembangannya. Selain itu, kebahagiaan anak menjadi faktor utama baiknya perkembangan anak, baik itu ketika berada di dalam rumah maupun di luar rumah. Oleh karena itu, orang tua harus bisa menciptakan lingkungan yang aman, nyaman, harmonis dan kasih sayang dalam keluarga untuk mempererat emosional orang tua dengan anak, terlebih lagi selama masa pandemi covid-19 yang mengharuskan anak dan orang tua harus terus menerus berada di rumah. Dalam mendorong kualitas pembelajaran pada Anak Usia Dini perlu kerjasama dan dukungan orang tua. Kerjasama dan dukungan orang tua saat pandemic covid 19 seperti memperkuat penanaman karakter jujur, tanggungjawab, percaya diri, mandiri, sopan, peduli, kerjasama, saling menghargai, kreatif dan sebagainya. Permasalahan utama dalam pengembangan nilai karakter pada anak adalah tidak konsistennya penerapan karakter dalam kehidupan sehari-hari. Sebaiknya pengajaran nilai-nilai karakter dapat dilakukan melalui contoh nyata yang dapat dilihat dan dirasakan anak dalam kehidupan sehari-hari.

Belajar di rumah bisa dilakukan dengan panduan orang tua. Walaupun di rumah anak didik harus diberikan edukasi yang positif dan produktif. Dengan adanya kemajuan digital yang sangat canggih, belajar di rumah bisa dilakukan dengan cara online tanpa bertatap muka dengan guru dan teman. Dengan adanya kondisi wabah COVID-19 kemajuan teknologi dapat memudahkan kehidupan secara efektif dan fleksibel. Untuk itu, dalam mengoptimalkan sistem belajar di rumah bisa berjalan dengan baik, diperlukan sarana dan prasarana pendukung yang baik pula seperti fasilitas internet dalam bentuk kuota belajar, fasilitas belajar sepertikomputeratau HP, dan sebagainya. Hal tersebut dapat diperuntukan agar kegiatan belajar atthehomedapat berjalan lebih

\footnotetext{
${ }^{21}$ Hendy Puspita Primasari. Tantangan dalam pembelajaran PAUD pada masa Pandemi. https://news.koranbernas.id/berita/detail/tantangandalam-pembelajaran-paud-pada-masa-pandemi diakses tanggal 15 Februari 2021
} 
efektif dan lebih efisien dalam pencegahan COVID-19 yang sangat berbahaya ini.

Situasi pandemi covid 19 ini, orang tua memiliki kesempatan dalam menanamkan nilai-nilai karakter dan nilai-nilai kehidupan bagi putra-putri dalam aktivitas seperti tadarusan, tarawih bersama, bersih-bersih, mencuci, memasak dan pekerjaan rumah tangga lainnya. Sesuatu yang sangat mengkhawatirkan saat ini adalah jauhnya keterlibatan putra putri dalam pekerjaan rumah tangga. Hal ini terjadi tugas-tugas karena kerumahtanggaan dikerjakan oleh asisten rumah tangga sehingga kurang mendapatkan perhatian orang tua dalam mendidik putra putrinya. Padahal keterampilan kerumahtanggan sangat diperlukan dalam mengasuh dan mendidik anak usia dini.

Orang tua menjadi salah satu pihak yang bertanggung jawab dalam keberlangsungan pendidikan anak usia dini di masa covid-19. Pengasuhan positif, penyediaan lingkungan belajar yang memadai, dan sumber belajar yang relevan akan sangat membantu anak usia dini dalam menjalani masa transisi menuju era new normal. Orang tua dalam menjalankan perannya dalam pendidikan harus terus menerus mendorong, membimbing, memotivasi dan menfasilitasi demi tercapainya tujuan pendidikan anak usia dini, yaitu anak dapat berkembang sesuai dengan potensinya masingmasing.

Komunikasi antara guru dan orang tua harus berjalan dengan baik. Kebijakan pemerintah tentang belajar dari rumah tidak serta merta membuat guru melepaskan tugasnya dalam memberikan pendidikan kepada anak usia dini. Justru hal tersebut menuntut guru untuk meningkatkan kompetensinya dalam melakukan pembelajaran jarak jauh dan tetap menilai perkembangan anak berdasarkan laporan kegiatan dari para orang tua. Selain dengan online maka guru juga mengintruksikan kepada siswa untuk belajar lewat media televisi. Program yang dijalankan oleh guru bekerja sama dengan Kemendikbud dengan menyajikan tayangan edukasi di TVRI dapat digunakan sebagai salah satu media pembelajaran online. Anak sesuai jenjangnya bisa menyaksikan program pembelajaran dari TVRI sesuai jadwal yang telah disampaikan oleh pihak televisi sesuai dengan jenjang pendidikan. 
Pembelajaran anak usia dini di masa covid-19 juga harus dalam suasana penuh kebebasan, nyaman, menyenangkan dan dipenuhi rasa aman. Kebebasan yang dimaksud tidak ditekankan pada kebebasan dari tanggung jawab, melainkan kebebasan dalam menyelesaikan masalah, cara belajar dan menciptakan sesuatu. Suasana belajar yang menyenangkan akan membantu anak menerima informasi dengan baik dan menempatkannya pada memori jangka panjang (long term memory).

Selama anak melakukan kegiatan bermain di rumah, orang tua berperan sebagai pendamping, fasilitator, motivator, dan melaporkan kegiatan yang dilakukan anaknya kepada guru sebagai bagian dari assessment perkembangan anak. Guru yang menerima laporan kegiatan anak selanjutnya akan menganalisis dan mencatat setiap aspek perkembangan anak. Dengan demikian terjalin sinergitas positif antara guru dan orang tua. Guru tidak membawa kurikulum baku yang ada di sekolah ke rumah. Olehnya, orang tua dapat berkreativitas menerapkan pembelajaran yang menyenangkan sesuai dengan situasi dan kebutuhan anak.

Selama berlangsungnya belajar dari rumah, guru maupun orang tua dapat memanfaatkan berbagai sumber belajar yang menunjang aktivitas belajar anak usia dini. Benda-benda yang ada di lingkungan sekitar rumah dapat dimanfaatkan sebagai pembelajaran anak usia dini. Anak dapat membangun dan megembangkan pembelajaran sesuai dengan minatnya sendiri dari barang-barang yang ada disekitar rumah.

\section{KESIMPULAN}

Pembelajaran dengan menggunakan sistem daring ataupun sistem online ini masih mengalami banyak problematika dalam penerapannya, karena anak tidak dapat belajar sendiri tanpa pendampingan dari orang dewasa yang paham cara mengoperasionalkan HP berbasis android. Ketersedian paket data juga menjadi hal yang perlu diperhitungkan dalam menerapkan pembelajaran. Anak usia dini merupakan anak yang sedang berkembang segala aspek perkembangan dan pertumbuhan pada dirinya dengan pesat. Akan tetapi, saat ini banyak orang tua yang kurang memahami akan hal ini. Bahkan ketika anak merasa bosan, orang tua mencari cara aman dan mudah untuk mengatasi hal tersebut, misalnya memberikan gadget pada anak. Hal ini 
sebaliknya akan memberikan efek kecanduan dan beberapa faktor kurang baik yang akan mempengaruhi perkembangan dan pertumbuhan anak. Apalagi selama pandemi covid-19 saat ini. Anak hanya berada di dalam rumah bersama orang tua, mengikuti pembelajaran daring dan melakukan semua kegiatan di dalam rumah, sehingga gadget menjadi sahabat anak dan sahabat orang tua selama belajar di rumah.

Komunikasi guru dan orang tua di masa pandemic covid19 harus terjalin dengan baik, karena Orang tua menjadi salahsatu pihak yang bertanggung jawab dalam keberlangsungan pendidikan anak usia dini di masa covid-19. Pengasuhan positif, penyediaan lingkungan belajar yang memadai, dan sumber belajar yang relevan akan sangat membantu anak usia dini dalam menjalani masa transisi menuju era new normal. Orang tua dalam menjalankan perannya dalam pendidikan harus terus menerus mendorong, membimbing, memotivasi dan menfasilitasi demi tercapainya tujuan pendidikan anak usia dini, yaitu anak dapat berkembang sesuai dengan potensinya masing-masing.

\section{DAFTAR PUSTAKA}

Echols, John M. dan Shadily, Hasan. Kamus Inggris-Indonesia. Jakarta: Gramedia, 2000.

Fahrina, et.al. Minda Guru Indonesia: Peran Guru Dan Keberlangsungan Pembelajaran di Masa Pandemi Covid19. Syiah Kuala University Press, 2020.

Hamid, Menyiapkan Pembelajaran Di Masa Pandemic: Tantangan Dan Peluang. Kementerian Pendidikan dan Kebudayaan, 2020.

Hewi, L., \& Asnawati, L. Strategi Pendidik Anak Usia Dini Era Covid-19 dalam Menumbuhkan Kemampuan Berfikir Logis. Jurnal Obsesi: Jurnal Pendidikan Anak Usia Dini, 5(1) 2020. https://doi.org/10.31004/obsesi.v5i1.530 
Jamaluddin, dkk., Pembelajaran Daring Masa Pandemi Covid-19 pada Calon Guru: Hambatan, Solusi dan Proyeksi. Bandung: UIN Sunan Gunung Djati Bandung, 2020.

Kahar, M. Iksan. Pendidikan Anak Usia Dini di Masa Covid-19, Ana' Bulava: Jurnal Pendidikan Anak 1, No. 2 (2020).

Kahar, M. Iksan. Pendidikan Karakter pada Anak Usia Dini dalam Perspektif Islam, Musawa: Journal For Gender Studies, Vol 11(01) 2019.

Khadijah, \& Gusman, M. Pola kerja sama guru dan orangtua mengelola bermain aud selama masa pandemi covid-19. Jurnal Kumara Cendekia, 8(2) 2020 .

Napitupulu, R. M. Dampak pandemi Covid-19 terhadap kepuasan pembelajaran jarak jauh. Jurnal Inovasi Teknologi Pendidikan, 7(1) 2020, 23-33. https://doi.org/10.21831/jitp.v7i1.32771

Palar, Jordan Efraim. Franly Oniba dan Wenda Oroh, "Hubungan Peran Keluarga dalam Menghindari Dampak Negatif Penggunaan Gadget pada Anak dengan Perilaku Anak dalam Penggunaan Gadget di Desa Kiawa 2 Barat Kecamatan Kawangkoan Utara", Volume 6 Nomor 2, 2008.

Primasari, Hendy Puspita. Tantangan dalam pembelajaran PAUD pada masa Pandemi. https://news.koranbernas.id/berita/detail/tantangandalam-pembelajaran-paud-pada-masa-pandemi diakses tanggal 15 Februari 2021

Pusat Bahasa Depdiknas, Kamus Besar Bahasa Indonesia. Jakarta: Balai Pustaka, 2005.

Republika, "Hubungan Ibu-Anak Hadapi Stres Social Distancing Covid-19”, Minggu, 22 November 2020. 
Sri, K. U. E-Learning: Technological Development in Teaching for school kids. International Journal of Computer Science and Information Technologies, 5(5), 2014. 6124-6126.

Sudrajat, dkk. Strategi Kepala TK dalam Meningkatkan Mutu Pendidikan pada Masa Pandemi Covid 19 Jurnal Obsesi : Jurnal Pendidikan Anak Usia Dini, 5(1) 2020. https://doi.org/10.31004/obsesi.v5i1.582

Suhendro, Strategi Pembelajaran Pendidikan Anak Usia Dini di Masa

Covid-19. Jurnal Golden Age, 5(3) 2020, 133-140.

Suhendro, Eko \& Syaefudin, Nilai-Nilai Kemanusian dalam Pendidikan Anak Usia Dini Inklusi. JEA (Jurnal Edukasi AUD), 6(1) 2020. https://doi.org/10.18592/jea.v6i1.3430

Tabi'in, A. Problematika Stay At Home Pada Anak Usia Dini Di Tengah Pandemi Covid 19, Jurnal Golden Age, Universitas Hamzanwadi Vol. 04 No. 1, Juni 2020.

Wilder-Smith, A., \& Freedman, D. O. Isolation, quarantine, social distancing and community containment: Pivotal role for old-style public health measures in the novel coronavirus (2019-nCoV) outbreak. Journal of Travel Medicine, 27(2) 2020, 1-4. https://doi.org/10.1093/jtm/taaa020

Zamzami, Elviawaty Muisa. Aplikasi Edutainment Pendukung Pembelajaran Jarak Jauh TK Merujuk Standar Nasional PAUD. Jurnal Obsesi : Jurnal Pendidikan Anak Usia Dini, 5(2) 2020. https://doi.org/10.31004/obsesi.v5i2.750 